\title{
Surviving the Global Recession and the Demand for Auto Industry in The U.S. - A Case for Ford Motor Company
}

\author{
Norikatsu Hiraide \\ Department of Mathematics, Computer Science and Economics, Emporia State University \\ 1200 Commercial St. Emporia, KS 66801, USA \\ Tel: 620-481-1927Ｅ-mail: nhiraide@emporia.edu
}

Kalyan Chakraborty (Corresponding author)

School of Business, Emporia State University, 1200 Commercial Street, Box 4057, Emporia, KS 66801, USA

Tel: 620-341-5913 E-mail: kchakrab@emporia.edu

$\begin{array}{lc}\text { Received: February 1, } 2012 & \text { Accepted: February 20, } 2012 \\ \text { doi:10.5539/ijef.v4n5p85 } & \text { URL: http://dx.doi.org/10.5539/ijef.v4n5p85 }\end{array}$

Presented at the International Conference on Business and Economic Issues, in New Delhi, India,Dec 19-21, 2011

\begin{abstract}
The world economy has been severely affected by the global recession which started from the second quarter of 2007 triggered by the financial crisis. The auto industry in the U.S. faced the most severe difficulties which threatened its survival after the recession. In the U.S. especially the "Big 3" the General Motors, Ford, and Chrysler struggled to stay in the business. This paper analyzes the impact of recent downturn on U.S. auto industry in general, and the demand of Ford vehicles in particular. The study also discusses the past and present performance of Ford Motor Company in the light of changing economic conditions at home and abroad. The empirical study uses twenty years sales data to estimate a time-series demand model for Ford vehicles.The study found that the demand for automobiles in the U.S is positively related to non-farm employment and single family housing start and negatively related to gas price and vehicle price.
\end{abstract}

Keywords: Vehicle, Error-correction, Time-series, Ford, Autocorrelation

JEL Code: F0, F4

\section{Introduction}

Historically after every postwar recession automobile industry has been one of the major forces in the U.S. economic recovery. Some industry analysts believe that the automotive sector has experienced the same bubble as the housing sector and that it will never return to prosperity (Boudette and Shirouzu, 2008). The Great Recession that began during the middle of 2007 due to the collapse of subprime mortgage market ushered in the worst financial crisis in seventy five years. The U.S auto industry, because of its forward and backward linkages, consumer spending reached near death in 2009 when GM and Chrysler both took government bailouts and entered into bankruptcy. The auto sales hit the 30-year low and employed half as many people as it did in 2000 (the peak was in 2007 with 1 million) (Krisher et al. 2009).

However, recent industry reports suggest automakers are hiring again and the auto sales are rising. Americans bought 10.6 million cars and trucks in 2009, 11.8 million in 2010, and 13 million in 2011 (WardsAuto, 2011). Compared to June 2009, auto industry's employment has increased by 12 percent by the end of 2011 although small but the employment creates a ripple effect on the economy. A study by the Center for Automotive Research (CAR, 2010) estimated that for every new auto manufacturing job creates nine other jobs from part manufacturing to restaurant employees. The CAR study found the impact of $\$ 80$ billion aid to GM, Chrysler, GMAC, and Chrysler Financial, saved 1.4 million jobs in 2009-10, prevented personal income loss of $\$ 76.5$ billion, and generated net gain for federal government in terms of changes in transfer payments, social security receipts, and personal income taxes $\$ 28.6$ billion. Many industry analysts wonder how Ford was able to overcome the recession while GM and Chrysler 
went bankrupt. What factors contributed to Ford's survival in the aftermath of the global financial crisis and earn record profit last year deserve a closer look from the industry standpoint.

This paper analyzes Ford Motor Company's past and present performances in the light of changing economic conditions at home and abroad and its adaptability to customers' tastes and preferences that has positively affected its sales. The objective of this study is to estimate the demand for Ford vehicles in North America and the factors influence the demand. The study uses twenty-year time series data on several macro-economic variables and applied cointegration and error correction models to determine the demand for Ford motor company. The study found that the demand for automobiles in the U.S is positively related to non-farm employment and single family housing start and negatively related to gas price and vehicle price.

The organization of the paper is as follows: the next section discusses some of the recent studies in automobile demand analysis followed by the methodology used in this study. The fourth section discusses the sources of data and reports the model results followed by a section on summery and conclusions.

\section{Recent Studies in Automobile Demand Analysis}

Automobile sales in the U.S. dropped significantly in the last recession compared to recessions in 1982 and 2001 due to three 'rough waves' - high gasoline prices, the credit crunch, and the job losses (Chu and Su, 2010). Historically housing market and automobile industry contribute significantly to U.S. GDP growth as a result when recession hits these two sectors it causes the major fall in GDP. From its peak during the fourth quarter of 2007 to second quarter of 2009 the U.S. GDP, residential investment, and auto production decreased from $\$ 13.3$ trillion, $\$ 525$ billion, and $\$ 402$ billion to $\$ 12.6$ trillion, $\$ 344$ billion, and $\$ 223$ billion, respectively. During this period the fall in GDP was 5.14 percent while the fall in residential investment was 34 percent and the fall in auto production was 44 percent (Table 1; Figure 1).

Thompson and Merchant (2009) found that employment and GDP growth among states in the U.S. are directly linked to increased revenue of U.S. automakers than the Japanese automakers, except for Toyota. Although, the overall economic scenario has improved in the last quarter of 2010 in terms of auto sales (rose by 43 percent) and GDP, but the housing market went downhill in all these years including 2011. Most of the researchers believe it will take a long time for the U.S. economy to return to its 2007 peak economic activities. According to an industry report (Ward's Yearbook, 2010) the lowest total vehicle sales in 2009 recession (10.6 million seasonally adjusted annual rate) was the lowest since 1981 (when 9 million vehicles were sold), although U.S. population is 30 percent larger in 2009 (307 million) than in 1981 (230 million).

In an effort to estimate the long-term automobile demand and determine the fundamental factors that drive the cyclical fluctuations $\mathrm{Chu}$ and $\mathrm{Su}$ (2010) simulated three scenarios for auto industry: downside, baseline, and upside. The study concludes that the recovery for the auto industry is inevitable and with a significantly different demographics and transportation infrastructure, the auto industry in the U.S. is unlikely to repeat the Japanese scenario. Japan's peak auto sales in 1990 were 7.6 million, falling to 6 million at the end of the decade and sales fell further to 4.5 million in 2009.

In their baseline scenario the authors predict that the auto sales would return to 12 million in 2010, up from 10.6 million in 2009, and rising steadily to 16.6 million in 2015. Plache (2011) argues that the consumer demand for auto purchases depends on " 3 C's" - cash (ability to pay), credit (ability to borrow), and confidence (motivation to buy). The study predicts that due to a large pent-up demand for automobiles during this recovery period auto sales may exceed all current and future projections.

Studies have found although the new vehicle sales are down during the last recession, the percentage of registered drivers in the U.S. remained stable over the last four decades even when the nation has experienced several oil shocks, recessions, and internet and technology revolutions. Although, the consumers are not buying the new vehicles the demand for used vehicles has gone up significantly and the price of used vehicles shows a sharp increase after the recession. Chu and Delgado (2009) explored the relationship between the demand for new vehicles and several other factors such as, the flow of new drivers into the market, changes in the average number of vehicles per driver, and the number of vehicles gets scrappage every year. The authors found that as Mexico progressively open the market for used car imports from USA from 2009 as per NAFTA regulation and fully liberalizing by 2019, the new vehicle sales in Mexico will reduce significantly and the new vehicle sales in the U.S will increase. The study estimates the loss of revenue to both auto makers and the Mexican government could reach as high as $\$ 100$ billion between 2009 and 2019. Due to non-availability of comparable sales data from competitive firms, the current study analyzes the factors determining the demand for Ford vehicles which is assumed to be the mirror image of the industry demand. A brief overview of the company, its products and services, and economic performance is provided below as a background for the analysis. 


\subsection{Brief Overview of the Company}

The Ford Motor Company was founded by Henry Ford and has based their operations in Detroit, Michigan since 1903. Through the years, the Ford Motor Company has expanded and progressed in their business operations to become one of the largest automobile manufacturers in the World. Ford has broadly defined two business wings: vehicle sales and services and financial and credit services. As of recently, Ford produces and sells vehicles under the Ford, Mercury, Lincoln, and Volvo brand names even though they have sold Volvo and shut down the Mercury brand names. Ford's main competitors in the United States are General Motors, Chrysler, Toyota Motor Corporation, Honda Motor Company, and Nissan Motor Company. In addition, its main competitors in Europe are General Motors, Volkswagen, PSA Group, Renault Group, and Fiat. In the past few years, Ford Motor Company has faced many challenges and overcame them as opposed to its American competitor General Motors Corporation. Ford was able to obtain sufficient loans to survive the U.S. recession in the last few years without a government bailout as opposed to General Motors. The subsequent reputation boost brought new customers and investors to Ford. In 2010, Ford was finally able to surpass Toyota and became the number two seller in the U.S after General Motors. That same year Ford's sales grew by 15.2 percent regardless of selling Volvo and closing Mercury (New York Times, 2011).

Ford's market position was extremely strong compared to their competitors. In 2010 Ford's net income was 6.56 billion higher than those of its main competitors General Motors and Toyota Motor Corporation (whose net income figures are $\$ 4.67$ billion and $\$ 5.93$ billion, respectively). Its operating margin of 6.9 percent was also the highest among the three. Ford's market share of the auto market was 16.2 percent, the second largest among the Big Five (General Motors, Ford, Toyota, American Honda, and Chrysler), and only 1.9 percent lower than General Motors (see Figure 2). Last year Ford became the best-selling automaker in Canada after more than 50 years, its sales are also increasing in China and India by 32 and 168 percent, respectively (Ford Annual Report, 2010).

\section{Methodology}

It is recognized in the auto industry that the demand for new vehicles depends on a host of factors such as, macroeconomic variables, social, government regulations, and technology. Researchers in automobile demand analysis found a fairly consistent set of variables influence long-run demand for automobiles. It is hypothesized in this study that the demand for new vehicles is negatively related to vehicle prices and gasoline prices and positively related to new housing starts, household income, and employment. We recognize that the price of competing vehicles has a positive impact on the Ford vehicle sales hence, should be included in the demand equation. But due to non-availability of comparable data for the period under study the empirical study excludes this variable. It is observed from the historical sales data that automobile sales are significantly lower during the periods of recession hence, a variable representing the year of recession is included as an explanatory variable in the regression. Following $\mathrm{Chu}$ and $\mathrm{Su}(2010)$ this study used cointegration and error correction model for demand analysis. The cointegration model is defined as:

$$
\text { Sales }=\alpha+\beta_{1} \text { V Price }+\beta_{2} \text { GP Pre }_{-1}+\beta_{3} \text { House }_{-1}+\beta_{4} \text { Emp }+\beta_{5} \text { Reces }+\varepsilon
$$

Sales $=$ units of Ford vehicles sold in North America; VPrice $=$ average price of Ford vehicles $(\$)$; GPrice $(-1)=$ average price of gasoline in the previous year (\$/gallon); House $(-1)=$ units of single family housing start in the previous year; Emp = total non-farm employment (million); Reces $=$ dummy variable (if recession year $=1 ; 0$ otherwise)

One of the major problems in regression analysis using time-series data is that the residuals are often not distributed uniformly around the mean - implying sudden large differences between the expected (fitted) sales and the actual sales. In such circumstances a dynamic structure of the demand equation is estimated incorporating the error term (residual) from the original cointegrating model as one of the independent variables along with the lagged value of the dependent variable, and the first difference of all other independent variables. The error correction model is defined below in equation (2):

Sales $=\alpha+\beta_{1}$ Sales $_{-1}+\beta_{2} V$ Price $(D)+\beta_{3} G$ Price $(D)+\beta_{4}$House $_{(D)}+\beta_{5}$ Emp $(D)+\beta_{6} \operatorname{Re}$ ces $+\varepsilon$

" $D$ " denotes difference in value of the variable between the current and the previous year.

\section{The Data and Analysis of the Results}

Annual data from 1990 to 2010 for units of vehicles sold by Ford came from Ford Motor's SEC filings and forms with the U.S. Securities and Exchange Commission (U.S. SEC, 2011). The data on average price of Ford vehicles are derived from the information on Ford's sales volume and revenue data from SEC filings for various years and Ford's $10-\mathrm{K}$ reports. The historical data on average annual retail price for gasoline are obtained from the U.S. Energy and Information Administration (USEIA, 1961-2010). The historical data on annual non-farm employment 
and GDP came from Bureau of Labor Statistics (BLS, 2011) and Bureau of Economic Analysis (BEA, 2011), respectively. The information on annual housing starts for single family is obtained from National Association of Home Builders (NAHB, 2011). Information on U.S. business cycle activities was collected from National Bureau of Economic Research (NBER, 2011). The descriptive statistics for the variables used in the study are reported in Table 2.

Initially, several macroeconomic variables such as, GDP, consumer credit flow, household income, and unemployment rate were tested for inclusion in the model but turned out insignificant hence, dropped out of the final model. Parameter estimates from the cointegration model (equation 1) are reported in Table 3. In terms of the explanatory power the model performs well and all independent variables have expected signs and are significant. However, low Durbin-Watson statistics suggests autocorrelation exists $(\mathrm{DW}<2)$, which is further evidenced when the residuals were plotted against the actual and the fitted values. The large spikes were observed for some years (Figure 3).

Next we estimated the error correction model (equation 2) and the results are reported in Table 4. Initially, the lagged values of the residuals from the cointegrating model $\left(\mathrm{R}_{-1}\right)$ were included as an independent variable in the error correction model but the results did not improve and DW statistics remained below 2. Hence, we decided to run the model with current residuals instead of lagged residuals. All independent variables, except for the first difference of vehicle price have expected signs and are significant. Gasoline price has a significant structural negative impact and housing start and non-farm employment have a significant positive structural impact on new car sales. One of the possible reasons for the 'first difference in annual vehicle price' variable not significant is that when automakers aggressively cut vehicle prices consumers generally buy higher grade cars rather than buying more cars, for example, entry-luxury cars rather than mid-size cars (Chu and $\mathrm{Su}, 2010)$. The results from this model are consistent with $\mathrm{Chu}$ and $\mathrm{Su}$ (2010). Overall the explanatory power of the error correction model (Table 4) did improved $\left(\mathrm{R}^{2}=0.9453\right)$ and the DW statistics is above 2. When residuals from this model are plotted (Figure 4) there were no signs of significant spikes.

Positive and significant coefficient on the residuals suggests the difference between the consumers' expectations about the future macroeconomic activities and the course of cyclical fluctuations in the current period would cause a significant positive impact on vehicle sales. The results from the cointegrating model (structural) and error correction model (cyclical) suggest that vehicle price has a significant structural impact (Table 3) but insignificant cyclical impact (Table 4) on Ford vehicle sales. The impact of gasoline prices, housing start, and non-farm employment are similar for both models. Negative signs on gasoline price and vehicle price suggest demand for new vehicles will decrease with the increase in value for these two variables. Intuitively, since the consumers generally spend a fixed amount of income on transportation, if the cost of acquiring and running a vehicle is either high at present or is expected to be high in the future, the demand for new vehicles will decrease.

\section{Summary and Conclusions}

This study investigates the impact of recent recession on the U.S. auto industry in general and the demand for Ford vehicles in particular. We found that the recession has greatly impacted the U.S. housing and auto industry, however from last quarter of 2009 auto sales are rising slowly and the industry is hiring more workers. The empirical evidence from this study shows that the recovery of sales for Ford vehicles in the future will depend on two set of factors: the macroeconomic factors such as, housing and employment; and cost factors such as, gasoline price and vehicle price. One of the drawbacks for this study is that the demand equation did not include the price of substitute vehicles (vehicles produced by competing firms) hence forecasting future demand based on current study would not be consistent and accurate. This study did not make any attempt to forecast future auto sales for Ford Motor Company based on our econometric model. However, the company expects that the overall auto sales will grow in 2012 due to economic recovery because, conventionally the auto market is expected to recover faster than the housing market since cars wear out sooner than houses.

With annual GDP growth expected to be 2.5 percent, current unemployment reaming at 8.5 percent, and gasoline price expected to be $\$ 3.70$ per gallon for 2012 Ford expects that the future demand will come from fuel efficient cars in the market. However, studies have found although the gasoline expenditure accounted for 5 percent of consumers' expenditure in 2007-09, a one-cent increase in gas price reduces consumption by 0.2 percent in terms of miles driven and not switching to more fuel efficient vehicles (Bento et al. 2009). Klier and Linn (2009) found that between 2002 and 2007 the half of the market share for U.S. automakers decreased due to an increase in gasoline prices. Ford has introduced new technologies to improve environmental friendly fuel efficient vehicles in the U.S. market. Ford Fiesta is evaluated as the most efficient subcompact car and Ford is currently in the process of 
producing ten next generation fuel efficient cars such as, Hybrid and Plug-in Hybrid cars. Ford is also planning to produce five all new electric vehicles by 2012 (Ford Annual Report, 2010).

Figure 5 ( $a, b, c$, and d) shows the annual fuel cost for running a Ford vehicle relative to its competitors' vehicles (car, pickup truck, SUV's, and overall). Figure 5(d) shows on average, Ford vehicles ranks $3^{\text {rd }}(\$ 2,966)$ for annual fuel cost (Honda being the lowest $\$ 2,834$, followed by Toyota $\$ 2,861$ ). Some industry analysts predict that future demand for automobile will greatly influenced by availability of new and stylized vehicles and auto transaction prices. With the rising inflation, average auto prices are expected to rise while vehicle incentives from auto manufacturers are expected to decrease. Plache (2011) found that for the industry as a whole the new vehicle prices increased by 5.7 percent and the average vehicle incentives decreased by 5.6 percent, the combination acted as a neutralizing effect on vehicle sales in the U.S. He believes that this trend will continue in the recovery phase in 2012 and beyond.

\section{Acknowledgement}

Authors acknowledge the contribution of Michael Barger, Lin Lin, Lu Kuo, Emad Moqbel, Wen Hong, and Zhou Hao graduate MBA students for their research assistance and comments in the earlier version of this paper during a class presentation in the spring 2011.

\section{References}

Bento, A. M., Lawrence H. G, Jacobsen, M. R., \& Von Haefen, R. H. (2009). Distributional and efficiency impacts of increased US gasoline taxes, American Economic Review, 99(3), 1-37.

Boudette, N., \& Shirouzu, N. (2008). Car makers' boom year now look like a bubble, The Wall Street Journal, May, 20 .

Bureau of Economic Analysis (BEA). (2011). National Accounts, Current and Real GDP at http://www.bea.gov/national/

Bureau of Labor Statistics. (BLS). (2011). Establishment Data Historical Non-farm Employment at http://data.bls.gov/pdq/SurveyOutputServlet

Center for Automotive Research (CAR). (2010). The impact on the U.S. economy of the successful automakers bankruptcies.Research Momentum.

Chu, T. H., \& Delgado, A. (2009).Used vehicle imports impact on new vehicle sales: The Mexican Case. Revista Analysis Economico, 24(55), 347-64.

Chu, T. H., \& Su, Y. (2010). Will the U.S. auto market come back? Business Economics, 45,253-265.

Ford Motor Company Annual Report. (1990-2011). http://corporate.ford.com

Klier, T., \& Linn, J. (2009). The prices of gasoline and the demand for fuel economy: evidence from monthly new vehicle sales data. Working paper, Federal Reserve Bank of Chicago, WP 2009-15.

Krisher, T., Rugaber, C. S., \& Wiseman, P. (2009). Auto industry seeing new life, inhiring spree, at http://www.boston.com/news/education

National Association of Home Builders (NAHB). (2011). Annual Housing Start, 1978-2010 at http://www.nahb.org

National Bureau of Economic Research (NBER). (2011). US Business Cycle Expansion and Contractions at http://www.nber.org/cycles

New York Times. (Jan 4, 2011). Detroit carmakers post sales gains as Toyota lags, retrieved from http://www.nytimes.com/2011/01/05/business/

Plache, Lacey L. (2011). Auto Sales Forecast 2011, at Edmunds Auto Observer, Jan 2011, website at Edmunds.com. U.S. Energy and Information Administration (USEIA). (Jul 5, 2011). Gasoline Historical Prices at http://www.eia.gov/oil_gas/

U.S. Securities and Exchange Commission Filings for Ford for various years at http://sec.gov/cgi-bin/browse-edgar Ward's Auto Industry Yearbook, U.S. Vehicle Sales by Company. (2010). at http://wardsauto.com/

WardsAuto U.S. Car and Truck Sales. (1931-2011). at http://wardsauto.com/keydata/historical/UsaSa01summary 
Table 1. Housing and Automobile Industry Contribution to U.S. GDP 2007:Q4 - 2010:Q4 (In 2005 \$)

\begin{tabular}{cccc}
\hline Quarterly Data & $\begin{array}{c}\text { Auto Production } \\
\text { (\$Bill) }\end{array}$ & $\begin{array}{c}\text { Residential } \\
\text { Investment(\$Bill) }\end{array}$ & GDP (\$Bill) \\
\hline 2007: Q4 & 401.799 & 525 & 13326 \\
2008: Q1 & 393.106 & 483 & 13267 \\
2008: Q2 & 352.855 & 463 & 13311 \\
2008: Q3 & 332.948 & 443 & 13187 \\
2008: Q4 & 268.086 & 415 & 12884 \\
2009: Q1 & 224.236 & 368 & 12663 \\
2009: Q2 & 223.098 & 344 & 12641 \\
2009: Q3 & 279.250 & 360 & 12695 \\
2009: Q4 & 288.378 & 342 & 12814 \\
2010: Q1 & 314.972 & 331 & 12938 \\
2010: Q2 & 312.851 & 350 & 13059 \\
2010: Q3 & 330.807 & 323 & 13140 \\
2010: Q4 & 320.787 & 326 & 13216 \\
\hline
\end{tabular}

Source: Bureau of Economic Analysis (GDP data revised July30, 2011)

Table 2. Descriptive Statistics of the Variables Used in the Study (Average for 1990 - 2010, Obs = 21)

\begin{tabular}{lllll}
\hline Variables & Mean & SD & Minimum & Maximum \\
\hline Ford Vehicles Sold(Units in '000) & 3,723 & 834.1 & 1,927 & 4,933 \\
Average Price(Dollars) & 18,705 & $3,261.4$ & 12,784 & 23,555 \\
Price of Gasoline(\$/gallon) & 1.64 & 0.640 & 1.017 & 3.213 \\
Single Family HomesStarts (Units in '000) & 1,132 & 338 & 445 & 1,716 \\
Total Non-farmEmployment (mill) & 125.08 & 9.86 & 108.38 & 137.6 \\
Recession (Yes = 1) & 0.285 & 0.463 & 0.000 & 1.000 \\
\hline
\end{tabular}

Table 3. Coefficient Estimates from the Cointegration (Structural) Model (Dependent variable $=$ Units of Ford vehicles sold in North America)

\begin{tabular}{lll}
\hline Variables & Coefficients & t-statistics \\
\hline Constant & -685.304 & -0.353 \\
Average vehicle price & $-0.248^{*}$ & -2.602 \\
Price of gasoline (previous year) & $-713.331^{*}$ & -3.643 \\
Housing start (previous year) & $0.578^{*}$ & 2.172 \\
Total Non-farm employment & $76.861^{*}$ & 2.758 \\
Recession (If yes = 1, otherwise 0) & $-419.322^{*}$ & -1.953 \\
R-squared & 0.8738 & \\
F-statistics & 20.78 & \\
Durbin - Watson Statistics & 1.22 & \\
\hline
\end{tabular}

*Indicates variable are significant at 5 percent or above level 
Table 4. Coefficient Estimates from the Error Correction (Cyclical) Model (Dependent variable $=$ Units of Ford vehicles sold in North America)

\begin{tabular}{lcc}
\hline Variables & Coefficients & t-statistics \\
\hline Constant & $1252.16^{*}$ & 3.626 \\
Units of vehicles sold (previous year) & $0.629^{*}$ & 6.772 \\
First difference in average vehicle price & 0.016 & 0.248 \\
First difference in price of gasoline & $-115.029^{*}$ & -3.365 \\
First difference in units of housing start & $1.248^{*}$ & 3.632 \\
First difference in total Non-farm employment & $110.591^{*}$ & 3.215 \\
Residuals from Cointegration Model & $0.477^{*}$ & 2.456 \\
R-squared & 0.9453 & \\
F-statistics & 40.35 & \\
Durbin - Watson Statistics & 2.07 & \\
\hline
\end{tabular}

*Indicates variable are significant at 5 percent or above level

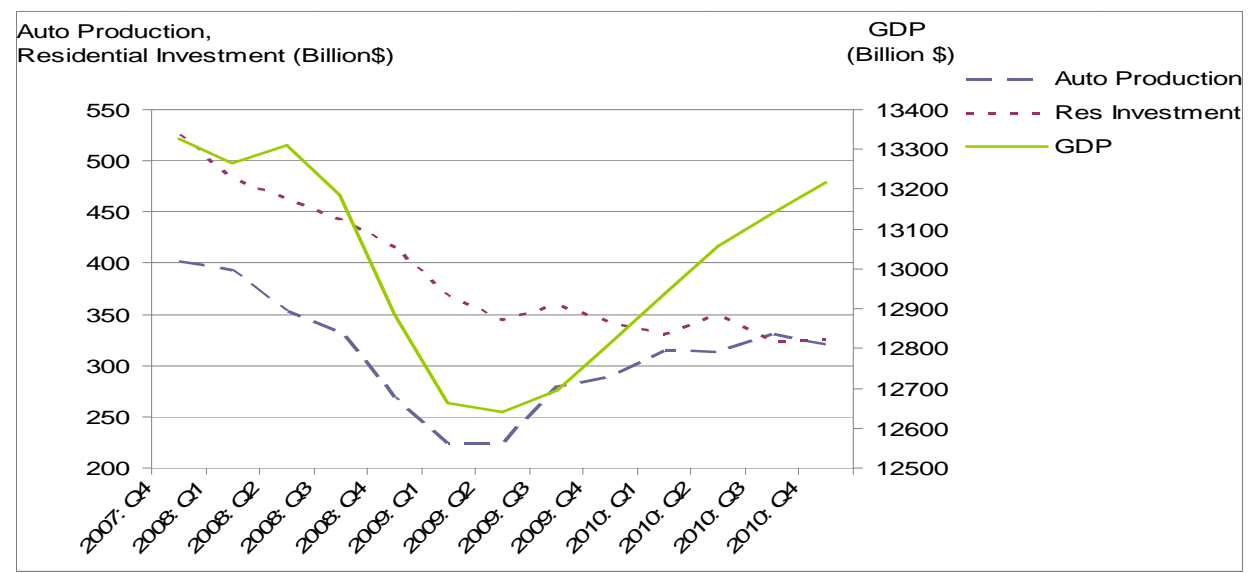

Figure 1. Housing and Automobile Industry Contribution to U.S. GDP

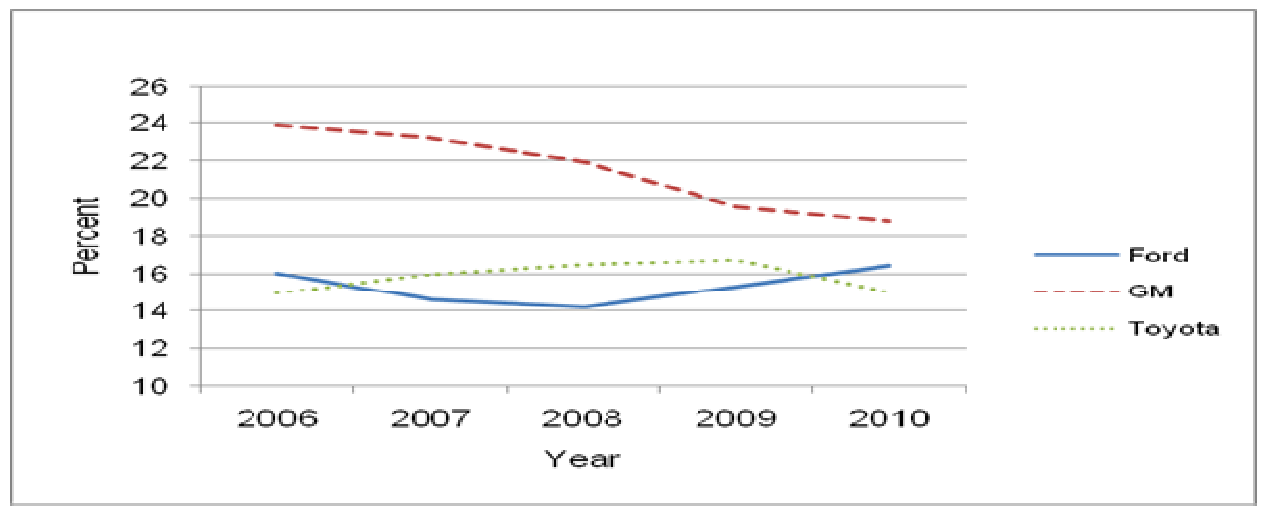

Figure 2. Big-3 Market Share in the U.S. (2006-10) 


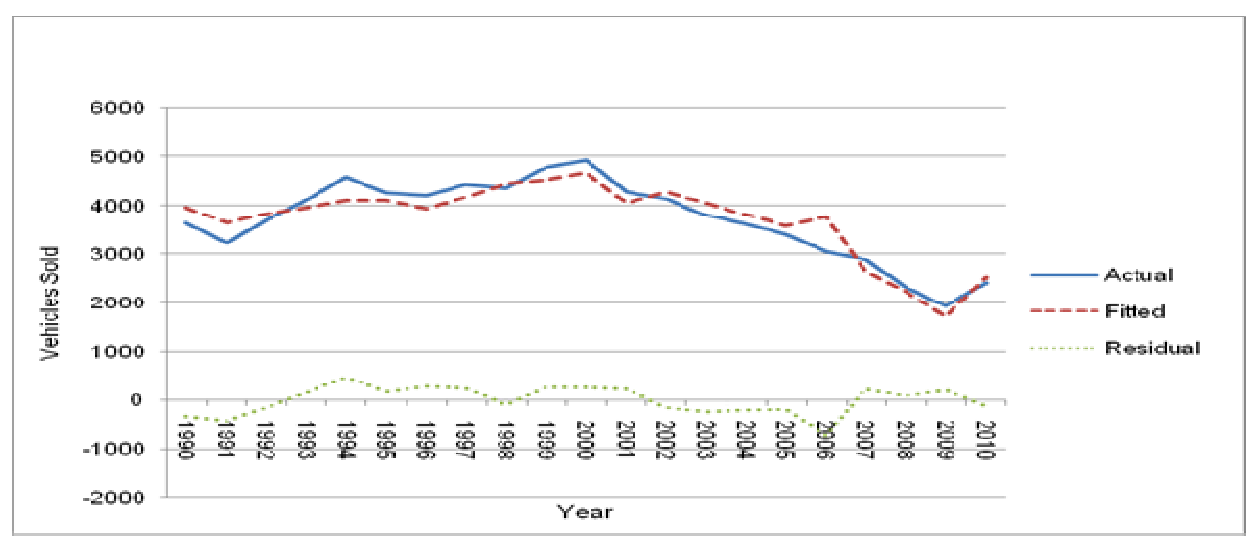

Figure 3. Actual, Fitted, and Residuals from the Cointegration Model

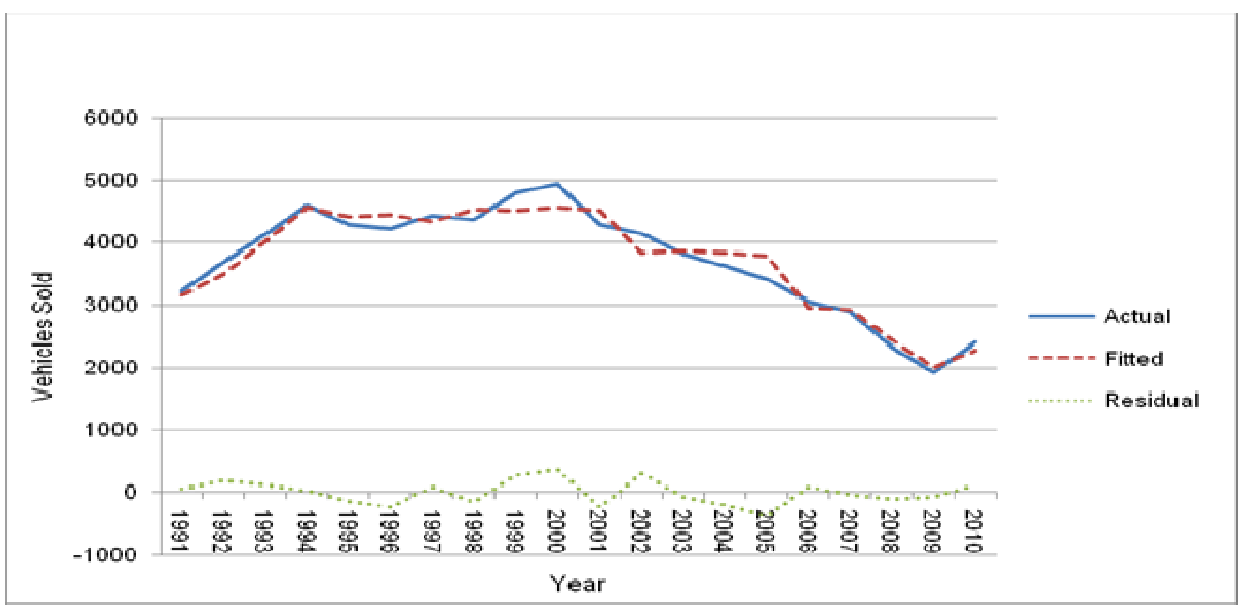

Figure 4. Actual, Fitted, and Residuals from the Error Correction Model 

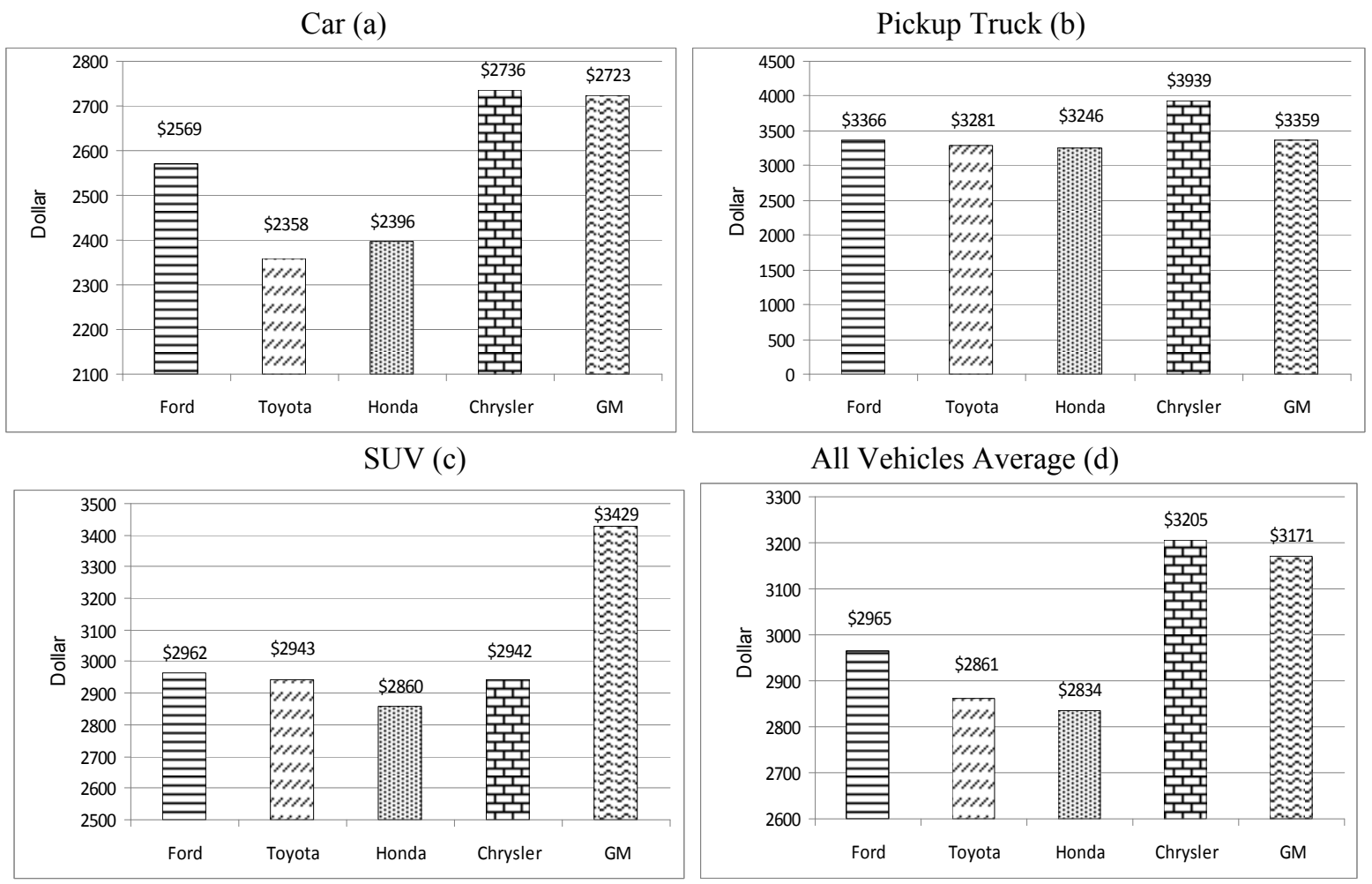

Source: http://www.fueleconomy.gov/

Figure 5. Average Annual Fuel Cost for Big-5 Automakers - 2011 